\title{
Meeting the health and social needs of married girls in India: The First Time Parents Project's implementation and reach
}

Population Council

Follow this and additional works at: https://knowledgecommons.popcouncil.org/departments_sbsr-pgy

Part of the Demography, Population, and Ecology Commons, Family, Life Course, and Society Commons, Gender and Sexuality Commons, and the International Public Health Commons How does access to this work benefit you? Let us know!

\section{Recommended Citation}

"Meeting the health and social needs of married girls in India: The First Time Parents Project's implementation and reach," update. New Delhi: Population Council, 2006. 


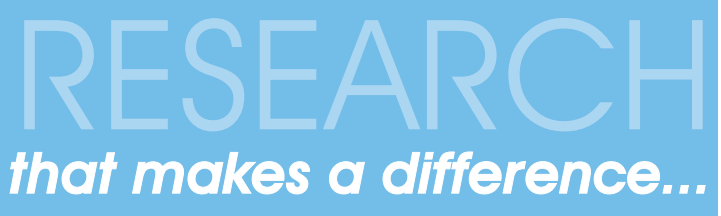

\section{MEETING THE HEALTH AND SOCIAL NEEDS OF MARRIED GIRLS IN INDIA: THE FIRST TIME PARENTS PROJECT'S IMPLEMENTATION AND REACH}

\section{Background}

India has one of the largest populations of married adolescent girls in the world. In fact, one-half of 20-24 year-old females were married by age 18, and close to a quarter of 20-24 year-old females were married before their 15th birthday (IIPS and ORC Macro 2000). A number of social and economic disadvantages are associated with early marriage. Married girls in India typically have low levels of educational attainment, limited or even absent peer networks, restricted mobility and less access to mass media than boys or unmarried girls or married adult women (Santhya and Jejeebhoy 2006a). For example, 45 percent of ever-married adolescents compared to 24 percent of 20-24 year-old females married at 18 years or above were not regularly exposed to any media.

In addition to these social disadvantages, girls who are married inevitably, and often promptly, face key reproductive health events. Most are regularly sexually active, and most are under pressure to have a first child. The evidence suggests that significant proportions of adolescents over one in five -give birth by age 17, the age below which obstetric risks appear to be particularly elevated. Yet married adolescents aged 18 or younger in India are significantly less likely than women aged 19-23 to use skilled delivery, or to fully immunize their children (Reynolds et al, 2006). Frequent and unprotected sex may also manifest as a risk of STI or HIV infection for married girls. A recent review of evidence reports that in a number of hospital-based, retrospective studies conducted among HIV positive women in India, a substantial proportion of infected women were young women whose only HIV risk factor was sex with their spouse (Santhya and Jejeebhoy 2006b).
Despite the high prevalence of early marriage and the distinct and predictable risks these girls and young women face, little is known about the lives of married young women, and little has been done to support them. In response, the Population Council, in partnership with Child in Need Institute (West Bengal) and Deepak Charitable Trust (Gujarat), initiated the First-Time Parents project. This project aimed to develop and test an integrated package of health and social interventions that would improve married young women's reproductive and sexual health knowledge and practices, and expand their ability to act in their own interests.

\section{Description of Project}

Intervention activities were conducted for two years, from January 2003 to December 2004, in 12 villages with a population of about 25,000 each in Diamond Harbour block in West Bengal and Vadodara block in Gujarat. Interventions in both sites focused on young women who were newly married, pregnant, or postpartum for the first time. Given their role as gatekeepers and confidants, husbands of these young women, as well as senior family members and health care providers were also included in project activities. Interventions comprised three mutually reinforcing components: information provision, healthcare service adjustments, and group formation.

A primary focus of the intervention was to directly provide married young women with information through home visits by female outreach workers, counseling sessions by providers in clinic settings, discussions in young women's groups and community activities such as health celebrations of health days or health weeks (such as breastfeeding week). Information was conveyed to men through home visits to young husbands by 
male outreach workers as well as via discussions in neighborhood meetings. Opportunistic interactions with mothers-inlaw and other senior women were sought to relay information to them as well. Issues included transmission and prevention of reproductive tract infections; contraception; sex as a voluntary and safe experience; development of a delivery plan; care during pregnancy and the postpartum period; breastfeeding; and how the husband could be supportive during this time.

As part of the intervention activities to encourage utilization of reproductive health services and to sensitize service providers, most government and private health providers (the latter including primarily unqualified, but much sought-after providers) in the project sites were oriented about the special needs of newly married, young couples and first-time parents. Refresher training on safe delivery was provided to traditional birth attendants. Condoms and oral pills were provided through home visits and clinics. Detailed information was offered together with existing antenatal services. Women and couples were helped to plan for delivery; traditional birth attendants were assured a supply of safe delivery kits; and referral and transport was supplied to young parents. Home visits from a health worker was provided to the mother and baby at two to six weeks postpartum; thereafter the mothers received bi-monthly follow-up visits for a year.

Finally, married young women's groups were formed to increase married girls' contact with peers and mentors, expose them to new ideas, and help them identify and articulate their point of view. With facilitation by project staff, groups established participant roles, chose a leader and deputy leader and learned to identify their needs and concerns. These groups typically met for 2-3 hours every fortnight. During these sessions, the groups took a participatory learning approach, covering topics such as legal literacy, vocational skills, pregnancy and postpartum care, available local resources (e.g., Government schemes that women can access and public amenities), gender dynamics within and outside the family, relationship issues, and nutrition. Ideas for topics and activities were identified by the girls themselves through activities such as community mapping and priority ranking of concerns. Exposure visits were made to places like the village administrative office, the bank, the post office, and active women's groups. The group members worked together on development projects, celebrated common festivals, and organized welcome ceremonies for newly married members. A few groups formed their own health funds through small savings from the group members to meet emergencies.

Monitoring data indicated that 1275 young women in Diamond Harbour and 1030 young women in Vadodara received home visits from an outreach worker. As expected, reaching husbands proved to be more difficult than reaching young women -- 847 young husbands in Diamond Harbour and 634 husbands in Vadodara had home visits during the intervention period. Monitoring data showed that 568 women in Diamond Harbour and 495 in Vadodara sought health services. Over 1,000 young women participated in group activities: 642 in Diamond Harbour, and 474 in Vadodara.

\section{Lessons Learned}

A quasi-experimental study with surveys at baseline and endline was conducted to assess the effects of the intervention on a number of domains including young women's agency and social networks, reproductive health knowledge and practices and partner support and communication. Analysis is underway and preliminary findings suggest improvements in young women's social networks, reproductive health knowledge and maternal and child health practices.

What is clear from the intervention experience is that it is feasible and is sustainable since it is not creating a new structure but orienting existing services to special needs of married adolescents and making links with existing programmes.
12 Population Council

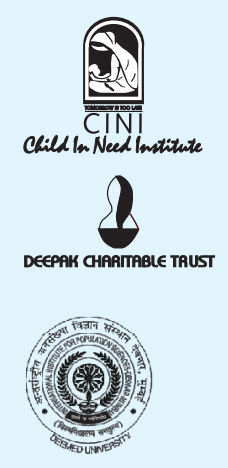

For further information please contact:

Population Council

Zone 5A, Ground Floor

India Habitat Centre, Lodi Road,

New Delhi - 110 003, INDIA

Tel: 91-11-2464 2901/02

Fax: 91-11-2464 2903

Email:info-india@popcouncil.org

wWW.popcouncil.org

K.G. Santhya, N. Haberland, S. Ghosh (Population Council); A. Das (Child In Need Institute); A. Lakhani (Deepak Charitable Trust); F.Ram, R.K. Sinha, U. Ram, S.K. Mohanty (International Institute for Population Sciences)

Donors

Department for International Development,

The Bill E Melinda Gates Foundation, The John D. and Catherine T. MacArthur Foundation,

The Andrew W. Mellon Foundation, Community Foundation for National Capital Region/The Summit Foundation

\section{References}

International Institute for Population Sciences (IIPS) and ORC Macro. 2000. National Family Health Survey (NFHS-2) 1998-99: India. Mumbai: International Institute for Population Sciences

Reynolds, H.W., E.L. Wong and H. Tucker. 2006. Adolescents' use of maternal and child health services in developing countries, International Family Planning Persepctives, 32 (1): 6-16

Santhya, K.G. and S.J. Jejeebhoy. 2006a. Early marriage and the risk of HIV/ AIDS among young women: Evidence from India (unpublished)

Santhya, K.G. and S.J. Jejeebhoy. 2006b. How early marriage compromises sexual and reproductive health: The situation and needs of married adolescent girls in India (unpublished) 